\title{
STAROST I STARENJE U ZRCALU DUHOVNOSTI
}

\author{
ANA ŠTAMBUK \\ Pravni fakultet, Studijski centar socijalnog rada, Zagreb, kontakt: astambuk@pravo.hr
}

Primljeno: 30.05.2017.

Prihvaćeno: 06.11.2017.

Pregledni rad

UDK: $159.913-053.9$

Sažetak: U radu je prikazana duhovnost kao područje koje sve više zauzima prostor u radu sa starijim osobama kako u zdravstvenoj tako i socijalnoj skrbi. U teorijama starenja rijetko se spominje duhovno i duhovnost. U teoriji psihosocijalnog razvoja duhovnost se može prepoznati u devetoj fazi, odnosno fazi gerotranscendencije. Prihvaćanje vlastite nemoći ili ovisnosti može biti izvor rasta, odnosno prilika za razvijanje duhovnih kvaliteta (strpljenja, zahvalnosti, užitka u malim stvarima, zadovoljstva što postojim $i$ živim), ali se također pruža nova prilika revrednovanja cjelokupnog života kroz davanje novog smisla svemu proživljenom. Prema razvojnoj teoriji pozitivnog starenja, osobe koje stare postupno se primiču meta-perspektivi, odnosno iz osjetne, opipljive, vidljive i materijalne vizije života i svijeta idu prema kozmičko-transcendentnoj viziji. Ukazano je na potrebu edukacije profesionalaca koji rade sa starijim osobama o važnosti prepoznavanja duhovnih potreba.

Ključne riječi: starije osobe, duhovnost, duhovne potrebe, gerotranscendencija, razvojna teorija pozitivnog starenja

\section{UVOD}

Gubici dragih osoba, životnih uloga, fizičkog i psihičkog zdravlja te pamćenja i neovisnosti mogu negativno utjecati na život starijih osoba. Poteškoće se javljaju i diskriminiranjem starijih osoba kroz shvaćanja da su oni društveni višak jer ne pridonose društvu na način koji društvo očekuje ili da jednostavno »nisu u trendu « te time postaju teret svojoj obitelji, ali i društvu. Danas se često starije ljude promatra kroz prizmu onoga za što oni više nisu sposobni, umjesto sagledavanja za što su još uvijek sposobni i što mogu razvijati. Sve ovo može utjecati na narušavanje samopoštovanja starijih osoba te smanjenje motiviranosti za daljnjim životom. Stoga duhovnost predstavlja plodonosno područje za rad na čovjekovom duhovnom blagostanju kroz koje i ostala životna područja mogu dobiti novu kvalitetu i smisao.

Mnogi istraživači naglašavaju da potraga za smislom u životu predstavlja centralni aspekt duhovnosti (McFadden, 1996; MacKinlay, 2001a, 2006; Ortiz, Langer, 2002; Aponte, 2002). Kada ne uspijemo zadovoljiti tu duboku potrebu život nam se čini ispraznim i bezvrijednim. Čovjek današnjice, unatoč tehnološkom i medicinskom napretku kao i općem boljem životnom standardu, često je opterećen besmislom te možemo čuti da je temeljna kriza našeg vremena duhovna kriza. Doživjeti duhovno znači biti u dodiru s većom, dubljom, bogatijom cjelinom koja našu trenutačnu ograničenu situaciju smješta u novu perspektivu. To znači da postoji nešto $s$ onu stranu, nešto više, nešto što nas nadilazi, čemu težimo, ono što našem sadašnjem, kao i prošlom i budućem životu i iskustvu daje značenje i vrijednost. Osvještavanje duhovne dimenzije može pojedinca potaknuti na veći društveni angažman, promjenu dotadašnjeg načina života, kvalitetnije odnose, veće zadovoljstvo životom, pronalazak snage za nošenje s teškim životnim situacijama poput bolesti, financijskih poteškoća i raznih gubitaka pa čak i osmišljavanje vlastite smrtnosti. Također se može manifestirati kroz prepoznavanje neke dublje razine istine ili ljepote, osjećaj pripadnosti većoj, kozmičkoj cjelini. Većina skrbi za osobe starije životne dobi naglašava njihove biološke, psihološke i socijalne potrebe. Novija istraživanja ukazuju da je duhovnost četvrta, zanemarena, dimenzija čovjeka koja obuhvaća cijelog čovjeka i njegovo iskustvo te daje smisao njegovom životu (Agostino, 1987; Ayele i sur. 1999; Baker, 2000; Bickerstaff i sur. 2003; Bondevik, Skogstad, 2000; Eisenhandler, 2005). Povećana duhovnost u starijoj dobi može biti povezana s očekivanjem boli i ograničenja, društvene isključenosti, blizine smrti kao i sa slobodama ste- 
čenim u toj dobi, uživanju u preostalim godinama i zadovoljnog pogleda na protekli život. Mnoga istraživanja (Ainlay i Smith, 1984; Markides, Levin i Ray, 1987; prema Schaie, Willis, 2001) ukazuju na podatak da sa starošću dolazi do smanjenja posjećivanja crkvenih obreda, ali se s druge strane povećava ili ostaje konstantno sudjelovanje u neorganiziranim obredima (osobne molitve, čitanje Biblije ili druge literature religioznog/duhovnog sadržaja). Svaki život završava fizičkom smrću, stoga se »duhovno putovanje« u starijoj dobi može sastojati od ispitivanja životnih postignuća i/ili iščekivanja smrti ali za neke iščekivanje života poslije smrti. Upravo je zadatak profesionalaca koji rade sa starijima da im pomognu suočiti se $s$ poteškoćama ali i izazovima starosti, osnažiti ih i ublažiti posljedice. Kvalitetno educirani profesionalci koji rade sa starijim osobama u bilo kojem području trebaju voditi brigu o jedinstvenoj duhovnosti svake osobe te njegovati individualni pristup.

\section{DUHOVNOST I DUHOVNE POTREBE STARIJIH OSOBA}

Tradicionalno su se duhovnima opisivale duboko religiozne osobe, no danas to uključuje tragače za religioznim, tragače blagostanja i sreće i na kraju sekularne osobe (Hill i Pargament, 2003). Duhovnost je izraz koji se sve više koristi u zdravstvenoj skrbi starijih osoba (Post i sur., 2000; Graves i sur., 2002; Pargament i sur., 2001; Sloan i sur., 1999), kao i u socijalnoj (Crisp, 2010; MacKinlay, 2006; Hall, Scragg, 2012; Jewell, 2011). Mnogi autori se slažu da je duhovnost vrlo teško definirati i da će se teško postići konsenzus oko definicije. Hill i Pargament (2003) ukazuju da duhovnost može biti shvaćena kao potraga za svetim, odnosno proces samootkrivanja u odnosu na sveto. McSherry (2006) navodi da se duhovnost doživljava i drugačije koristi od strane svakog pojedinaca te da predstavlja složeno i subjektivno područje. Također ističe da upravo radi toga stvaranje jedinstvene definicije može biti teško. MacKinlay (2001) navodi da duhovnost uključuje potrebu za konačnim smislom u svakoj osobi, bilo da se to ispuni kroz odnos s Bogom ili nekim drugim, bilo da neka druga vrijednost postane vodeća snaga u životu pojedinca. Ona također ističe da duhovnost uključuje odnos s drugim ljudima te da je duhovnost dio svakog ljudskog bića, odnosno upravo ono specifično humano, ono što razlikuje čovjeka od ostalih životinjskih vrsta. Autorica nastavlja opisujući dvije komponente duhovnosti, generičku i specifičnu. Generička duhovnost je središnje mjesto u svim ljudima i izražava se traženjem smisla i svrhe u životu, dok se specifična odnosi na način kako se svaki pojedinac bavi duhovnim u svom životu. To može biti kroz religioznost, odnose ili nešto drugo što daje smisao životu. Frankl (2010) definira duhovnost kao ljudsku potragu za apsolutnim smislom te ističe da smisao treba biti specifičan i imati svrhu za svakog pojedinca osobno. Murray i Zentner (1989) ističu da u svakom ljudskom biću postoji duhovna dimenzija, kvaliteta koja prelazi religiozna opredjeljenja i koja stremi ka inspiraciji, čuđenju, smislu i svrhovitosti, pa čak i kod onih koji ne vjeruju u Boga. Ova dimenzija teži biti u skladu s univerzumom, traži odgovore na pitanja u svezi vječnog te se pogotovo javlja u vrijeme emotivnog stresa, bolesti, gubitka, žalovanja i smrti. Duhovnost se može mijenjati tijekom životnog ciklusa kao što se mijenjaju i prioriteti tijekom života. Parsons (2001) smatra da jedna razina razumijevanja duhovnosti uključuje saznanje o putu osmišljavanja svog života i identiteta, dok se s druge strane radi o prakticiranju vjere kroz rituale i odnose s drugim ljudima. Koenig, King, Carson (2012) navode da tradicionalno povijesna definicija vidi duhovnost kao karakteristiku duboko religiozne osobe te ju razlikuje i odvaja od površno religiozne osobe. Duhovnost je za duboko religioznu osobu životni put koji dominira njenim pogledom na svijet, odluke, ponašanje, odnose s drugima. Kao model navode Majku Tereziju, Martina Lutera Kinga, Mahatmu Gandija i Siddhartu Guatama. Ova definicija vidi duhovnost kao komponentu religije, odnosno ne možeš biti duhovan ako nisi religiozan. Moderna definicija duhovnost vidi kao širenje izvan religije (Koenig, King, Carson, 2012). Ovaj pogled na duhovnost ne uključuje religioznost, odnosno kreira se nova kategorija ,duhovan ali nereligiozan pojedinac". Zinnbauer i dr. (1997, prema Koenig, King, Carson, 2012) opisuju ove osobe kao bolje educirane, s visokim primanjima, koje su u prošlosti imale loša iskustva u svojim religijskim zajednicama, a sada imaju vjerovanja i praksu u okviru New Age pokreta, vide se neovisnima o drugim ljudima i manje se žele žrtvovati za druge. 
Prema Moffit (1999) duhovne potrebe su povezane s vjerskim uvjerenjima i potrebom za vjerskim obredima u želji da se razumije samog sebe. To uključuje dublje razumijevanje i drugačije promišljanje životnih iskustava, odnosno traženje njihovog smisla. Koenig (1994) definira duhovne potrebe kao svjesno ili nesvjesno stremljenje koje proizlazi iz utjecaja ljudskog duha na biopsihosocijalnu prirodu. On navodi četrnaest duhovnih potreba kod starijih osoba:

- potrebu za smislom, svrhom i nadom,

- potrebu za transcendiranjem (nadilaženjem) okolnosti,

- potrebu za podrškom u nošenju s gubitkom,

- potrebu za kontinuitetom,

- potrebu za vrednovanjem i podrškom religioznog ponašanja,

- potrebu za uključenjem u religiozna ponašanja,

- potrebu za osobnim dostojanstvom i osjećajem sposobnosti,

- potrebu za bezuvjetnom ljubavlju,

- potrebu za izražavanjem ljutnje i sumnje,

- potrebu za osjećajem da je Bog na njihovoj strani,

- potrebu za ljubavlju i služenjem drugima,

- potrebu za zahvalnošću,

- potrebu za davanjem i primanjem praštanja,

- potrebu za pripremom za smrt i umiranje.

MacKinlay (2001) ističe da je duhovni razvoj kontinuiran tijekom cijelog života te da zdravo starenje ovisi o duhovnom zdravlju i blagostanju jednako kao i o fizičkom i psihosocijalnom. Duhovno zdravlje može biti poboljšano ako starije osobe senzibiliziramo za njihovo vlastito duhovno putovanje, prepoznamo duhovne potrebe kod krhkih i bolesnih starijih osoba te im pomognemo da uspješno otkriju vlastite duhovne potrebe.

\section{Duhovno iskustvo u starijoj životnoj dobi}

Profesionalci koji rade sa starijim osobama u praksi trebaju znati da njega usmjerena na osobu, poštivanje osobe i njenog dostojanstva kao i uključivanje i osnaživanje osobe - postaju značajni jedino ako su istinski povezani s »pričom« te osobe, tj. njenim životom, odnosno onim što je proživjela (Tooth i Linell, 2012). Pričanje priče (o raznim životnim iskustvima, životnim prekretnicama, iskustvima koja su jako utjecala na život osobe, gubicima, važnim osobama i odnosima s njima, itd) je put povezivanja s drugima, ali istodobno $\mathrm{i}$ traženje smisla u priči koji se nalazi upravo kroz pričanje. Ako se priča ne ispriča, životni smisao nije jasan (MacKinlay, 2006). Također, MacKinlay navodi da pričanje životnih događaja može doprinjeti liječenju prošlosti kao i pozitivnom pogledu na budućnost. Coleman (1999) opisuje da su karakteristike »uspješno ispričane priče« postizanje sklada i mira između prošlosti, sadašnjosti i budućnosti. Potraga za duhovnošću i duhovnim iskustvima jednako je važna čovjeku kao i njegove svakodnevne borbe za opstanak, stvaranje i razvoj. Ljudi većinu svoje pažnje usmjeravaju na ono što je vidljivo i opipljivo. Ono po čemu se zapravo razlikuje važnost svakodnevnih preokupacija i duhovnih iskustava je razina svjesnosti o njima. Duhovna iskustava postaju posebna i važna tek kada pronađemo smisao u dosadi i patnji, ali i užicima i zabavi. Tooth i Linell (2012) smatraju da se duhovnost manifestira i razvija kroz pet procesa koji čine cjelinu, model: promišljanje o ljudskoj duhovnosti ili ljudskom duhu, reflektirajuće središte, vjerovanja, akcije, duhovno iskustvo.

1. Ljudski duh promišlja, traži smisao i svrhu života, vrijednosti, preispituje sebe o razlogu svog života na zemlji. Ovo je zajedničko svim ljudima i može predstavljati polaznu točku za razgovor profesionalaca sa starijim osobama što će značajno povećati njihove mogućnosti da dopru do osobe i pomognu im na odgovarajući način. U istraživanju koje je provela Mowat (2004) intervjuirajući starije osobe o uspješnom starenju i duhovnom putovanju, ispitanici su govorili o sebi i svom životu kao »još nedovršenoj priči«. Bez obzira na dob imali su očekivanja, ciljeve i želje. Uspješnost su povezivali s cijelim životom, a ne sa starenjem kao fazom koja je odvojena od cjeline života. Možemo zaključiti da upravo ljudski duh predstavlja »moderatora« koji promijenjenim okolnostima i sposobnostima daje novi smisao.

2. Reflektirajuće središte - kako bi prethodno spomenuti proces imao smisla trebamo znati da postoji urođena osobina u svim ljudima - 
savjest, koja je sposobna odražavati i određivati što je prihvatljivo i dobro, istinito i korisno. Ona oblikuje naša iskustva, daje smisao životu, drži nas u vrijeme krize, ali i blagostanja.

3. Vjerovanja - ljudi razvijaju vlastiti ili preuzimaju tuđi sustav vjerovanja, filozofiju i vrijednosti kako bi oblikovali svoje duhovne priče ili kako bi spoznali što je sveto i uzvišeno. Duhovnost nam može pomoći da shvatimo kakvi želimo biti te kako da to i postignemo. O tome trebamo promišljati na jednostavan način kao što promišljamo i o željenim situacijama u radnoj okolini, društvu i načinu da to ostvarimo.

4. Akcije su nam potrebne kako bismo izrazili i razvili svoja vjerovanja i vrijednosti, kako bismo ih testirali u stvarnom svijetu, dali smisao našim vezama s drugima u okolini i otkrili ima li naše duhovno iskustvo neko značenje. Duhovnost možemo pronaći u svakodnevnim aktivnostima koje obavljamo i u našem svakodnevnom okruženju. Upravo zbog toga je važno osigurati aktivnosti starijim ljudima koje će njima nešto predstavljati i biti značajne za njih. Starije osobe možda nisu u mogućnosti obavljati mnoge aktivnosti (u kojima su prije uživale) zbog svog stanja, no zadatak stručnjaka je da pronađu načine kako u novoj situaciji otkriti smisao i radost. Kitwood (1997) navodi da i oboljeli od demencije mogu zadržati postojeću ili čak unaprijediti svoju razinu duhovnosti te da se smanjenjem kognitivnih sposobnosti povećava osjetljivost njihovih osjetila, emocija i duhovnosti. Mogućnosti su beskrajne, važno je razgovarati s njima, uključiti u ovaj proces i njima drage osobe (članove obitelji, prijatelje) opažati što je njima važno te se usuditi biti hrabar i kreativan. Pri tome se stručnjaci trebaju interesirati o vjerovanjima, vrijednostima i kreativnim sposobnostima svake pojedine osobe te poticati pozitivne emocije, usmjeravajući ih na njihove jake strane, na ono što još mogu napraviti.

5. Duhovno iskustvo se odnosi na posebnu vrstu iskustva koje predstavlja uzvišenu ili višu razinu svijesti koja uključuje malo ili nimalo osjećaja za »ja«. Odnosi se na iskustvo zajedništva, sklada i integracije. Ovo iskustvo često se razvije kroz dosljedna postupanja unutar vrijednosnog sustava, ali se može razviti i spontano tijekom čovjekova života. Kvalitete duhovnog očituju se konstantno kroz naš život i trebamo ih posvješćivati. Tako nam duhovnost pomaže da živimo u skladu s napetosti koju izaziva potreba da oblikujemo sami sebe, ali i da nas drugi oblikuju kroz naše odnose s njima.

Treba napomenuti da je duhovnost često shvaćena kao apstrakcija, nešto što baš i nema veze sa životom. Upravo prikazani model duhovnosti govori suprotno. Duhovnost prožima kompletnu ljudsku osobu: misli, uvjerenja, odluke, aktivnosti i na kraju dovodi do duhovnog iskustva. Kako pojedinačno iskazujemo našu duhovnost ovisi o našoj povijesti, kulturi i našim trenutnim namjerama i potrebama. U radu sa starijim osobama stručnjaci trebaju stvarati i podržavati uvjete koji će duhovno iskustvo učiniti mogućim (MacKinlay, 2001a).

\section{TEORIJE STARENJA I DUHOVNOST}

Teorije koje se bave procesom starenja mogu se podijeliti na biološke, sociološke i psihološke. Biološkim je teorijama zajedničko da pokušavaju objasniti uzroke i proces starenja na razini stanica, organa i organizma. Sociološke teorije starenja imaju za cilj objasniti promjene u odnosu pojedinca i društva do kojih dolazi u procesu starenja (promjene u ulogama, socijalnim aktivnostima, interakcijama). Također, bave se utjecajem društva i kulture na starenje pojedinca i obratno. Psihološke teorije starenja usmjerene su na dva pitanja: kako dolazi do organizacije ponašanja s vremenom te u kojim okolnostima dolazi do dezorganizacije ponašanja s vremenom (Despot Lučanin, 2003:23). Budući da cilj ovog rada nije prikaz postojećih teorija starenja, one neće biti sustavno navedene niti elaborirane. Ovdje ćemo spomenuti Eriksonovu teoriju psihosocijalnog razvoja s devetom fazom, koju je post mortem dodala njegova supruga Joan i nazvala gerotranscendencija te razvojnu teoriju pozitivnog starenja Larsa Tornstama, koju on također naziva gerotranscendencija - a o kojima u našoj gerontološkoj literaturi nema zabilješki.

\section{Teorija psihosocijalnog razvoja}

Teorija psihosocijalnog razvoja Erika Eriksona (Erikson, 2008) govori o ljudskom razvoju i 
sazrijevanju od rođenja do smrti. Mogli bismo reći da naš cijeli život predstavlja jedan put na kojem imamo mogućnost izbora, a u tome važnu ulogu imaju naši roditelji i okolina u kojoj živimo i radimo. To se odvija kroz osam faza u kojima se osoba suočava s krizama odnosno izazovima čiji ishod može biti pozitivan ili negativan. U svakoj fazi je naglasak na razvoju ega, a način na koji osoba razriješi svaki stadij utječe na budući uspjeh ili neuspjeh u svladavanju sljedećeg razvojnog stadija. Pozitivan ishod svakog stadija rezultira osobnim rastom. Prema Eriksonovoj teoriji uspješni prijelazi kroz razvojne stadije života vode sintezi koja može biti osnova za razvoj prema zadnjem stadiju - starosti. U ovoj fazi pojedinac može imati osjećaj integriteta ili očaja, a karakterizira ju procjena cjelokupnog vlastitog života. Ukoliko je pojedinac uspješno riješio ranije krize te u svom životu otkrio smisao i red, on tada postiže osjećaj cjelovitosti, unutrašnje jedinstvo ličnosti, odnosno integritet ega. Vrednota koja proizlazi iz ove faze je mudrost. Ako se ne dostigne integritet i ne otkrije smisao svega što smo u životu napravili (uspjeha i neuspjeha) prijeti osjećaj promašenosti, beznađa, depersonalizacije, straha, depresije i očajanja pred skorom smrću. Beznađe se izražava kroz osjećaj da je ostatak života prekratak za pokušaj novog života i isprobavanje alternativnih puteva do integriteta. Joan Erikson, supruga i suradnica Erica Eriksona, smatrala je da se deveta faza razvoja, koju je njen suprug Erik zaboravio, odvija u osamdesetim i kasnijim godinama života i nazvala ju je gerotranscendencija. U suočavanju s poteškoćama koju donosi duboka starost je izazov koji možemo pozitivno razriješiti na način da se iz materijalističkog i racionalističkog pogleda okrenemo ka kozmičkom i transcendentnom (Erikson \& Erikson, 1997). Naime, u dubokoj starosti psihičko i fizičko zdravlje počinju naglo slabiti, gubi se većina prijatelja i članova obitelji, a pojam smrti postaje bliska stvarnost. Ovu fazu često obilježava gubitak neovisnosti, samopoštovanja i povjerenja, a osoba u ovoj dobi postaje potpuno ili djelomično ovisna o tuđoj pomoći. Također, Joan Erikson navodi da je u ovoj devetoj fazi osoba ponovno u situaciji konfrontacije s prethodno razriješenim odnosno nerazriješenim fazama, odnosno na neki način prolazi ponovno kroz cijeli svoj život. Dakle, osoba je ponovno u mogućnosti izbora - izbora između prihvaćanja, odnosno otpuštanja dotadašnjih sposobnosti, načina života, posjedovanja i kontrole nad materijalnim dobrima. Također, u mogućnosti je drugačije prihvatiti, odnosno na drugačiji način vrednovati ono što je proživjela. Upravo u novoj, ovisnoj fazi, prihvaćanje vlastite nemoći može biti izvor rasta, odnosno nadilaženje poteškoća razvijanjem duhovnih kvaliteta kroz gerotranscendenciju. Tako npr. Kitwood i Bredin (1992) navode da se starije osobe oboljele od demencije, koja je uzrokovala djelomični ili potpuni gubitak kognitivnih sposobnosti, više ne promatra kao cjelovito biće. Dominantni oblici njege često dehumaniziraju takve ljude kroz ignoriranje, omalovažavanje i ismijavanje. Dalje navodi da oboljeli od demencije mogu zadržati postojeću ili čak unaprijediti svoju razinu duhovnosti. Stručnjaci koji rade sa osobama s demencijom trebaju razviti vještine pristupa potencijalima svake pojedine osobe (npr. što je osoba voljela, koju je glazbu slušala, koji rituali su joj bili važni, kako se opuštala itd). Možemo zaključiti da upravo doprinos Joan Erikson kroz devetu fazu psihosocijalnog razvoja otvara put ka novom promišljanju o mnogim gubicima, kao i novim mogućnostima s kojima se susreću starije osobe. Pitanje je možemo li danas kao pojedinci i društvo usmjereni prema profitu i materijalnim vrednotama, zastati i poštovati cjelovitost i raznovrsnost ljudskog životnog iskustva koje nadilazi naše osobne iskustvene i vrijednosne okvire? Naime, prisutnost neke bolesti, npr. demencije, ne lišava nas naše biti čovječnosti. Naprotiv, najveća prijetnja našem dostojanstvu kada smo bolesni je pogrešno predstavljanje nas kao osoba od strane drugih (članova obitelji ili stručnog osoblja), neosjetljivost u sustavu skrbi (česta pojava je medikalizirani pristup) i stereotipiziranje bolesti (O’Neill, 2009; prema Tooth i Linell, 2012).

\section{Razvojna teorija pozitivnog starenja - gerotranscendencija}

Transcendencija znači »prelaženje preko«, na viši stupanj, podrazumjeva napuštanje stare radi potpuno »nove« spoznaje, prelazi granice osjetnog iskustva. Pojam gerotranscendencije opisuje se kod starijih osoba kao viši nivo spoznaje 
i podrazumijeva one trenutke kada osoba ima intenzivno i neobjašnjivo iskustvo i svijest koja nadilazi osobnu dimenziju (Crisp, 2010). Možemo ju razmatrati i kao trenutak »prosvjetljenja« koji proizlazi iz susreta s drugim, u kojem nastojimo uvidjeti smisao naših iskustava i osvijestiti naše potrebe i želje za povezanošću, identitetom i smislom. Gerotranscendentno stanje Tornstam opisuje riječima kao što su duh, bezgraničanost, spajanje (Tornstam, 1989). Prema teoriji gerotranscendencije starije osobe se postupno primiču meta-perspektivi, tj. iz osjetne, opipljive, vidljive i materijalne vizije života i svijeta idu prema kozmičkotranscendentnoj. Ovo skretanje u meta-perspektivu može uključivati povećanje osjećaja zajedništva s duhom univerzuma, redefiniranje percepcije vremena, prostora i objekata, redefiniranje poimanja života i smrti, smanjenje ili potpuno odsustvo straha od smrti, povećanje osjećaja zadovoljstva prema prošlosti (prihvaćanje cjelovitosti života kroz uspjehe i neuspjehe), radovanje generacijama koje dolaze, smanjenju interesa za prekomjerne društvene akcije te provođenje više vremena u meditaciji (Tornstam, 1994). Tornstam smatra da ono što gerontolozi nazivaju distanciranje i povlačenje zapravo upućuje na pozitivan razvoj prema gerotranscendenciji. Tendencija starijih osoba prema gerotranscendenciji univerzalna je i neovisna o kulturi, iako je kulturni faktori mogu ubrzati ili usporiti. Tornstam (2000) opisuje promjene koje ljudi iskuse na putu prema gerotranscedenciji kroz tri razine: osobnu, socijalnu i kozmič$k u$. Osobna razina obuhvaća otkrivanje skrivenih aspekata vlastite osobe, uklanjanje svoje osobe iz centra univerzuma, brigu o tijelu bez opsesije, promjenu od egoizma ka altruizmu. Socijalna razina obuhvaća smanjeni interes za površne odnose i povećanu potrebu za samoćom, razumijevanje razlike između svoje osobe i uloge, suzdržanost u donošenju sudova i davanju savjeta. Kozmička razina obuhvaća promjene u definiciji vremena $i$ prostora, povećan osjećaj povezanosti s prirodom i svemirom, gubitak straha od smrti te povećani afinitet prema prošlosti i budućim generacijama. $U$ gerotranscendencijskom procesu mijenja se i percepcija koju osoba ima o sebi. Tornstam upućuje na Eriksonov razvojni model gdje je ego integritet cilj starije dobi. On se distancira od postupnog razvoja prema ego integritetu i govori o paradoksu gero- transcedencije koji u sebi sadrži radikalni raskid s prošlosti, odnosno smatra da je proces nadilaženja i napuštanja ega kontinuiran cjeloživotni proces. Tornstam ističe kako i ego u starosti treba postati transcendentan što bi pojedincu pomoglo u prevladavanju straha od smrti (Tornstam, 1989).

Provedena su brojna istraživanja u Švedskoj (Tornstam, 1994, 1996, 1997), Iranu, Turskoj (Lewin \& Thomas, 2001) i Kini (Liang, 2011) koja govore u prilog gerotranscendenciji. Interpretacija teorije gerotranscendencije od medicinskih sestara pokazuje da su one u svom radu sa starijim osobama prisutnost transcendentnih znakova interpretirale kao patologiju te da im je upravo ova teorija pomogla da ih prihvate kao znakove normalnog starenja i razviju pozitivne stavove prema starijim osobama (Wadensten \& Carlsson, 2001). Također su napravljene smjernice za vođenje sestrinske prakse koje se temelje na ovoj teoriji (Wadensten \& Carlsson, 2003). Weiss (2013) je istraživala posttraumatski rast i gerotranscendenciju te zaključuje da posttraumatski rast može biti shvaćen kao dio normalnog razvoja kod odraslih i kao pokretač gerotranscendencije. Rezultati istraživanja o povezanosti smisla života i boljeg fizičkog zdravlja također govore u prilog teoriji gerotranscendencije (Krause, 2004).

Navedena teorija predstavlja novi pogled na starost i starenje kao dio čovjekovog života koji upućuje na daljnja istraživanja ne samo u području gerontologije, nego i filozofije, medicine i antropologije, čiji će zajednički cilj biti pronalazak humanih i etičnih načina u susretu sa složenom problematikom starijih osoba, njihovih obitelji i drugih profesionalaca koji o njima brinu kao i traženju odgovora na pitanje o složenosti ljudskog života i njegovog potencijala za rast i razvoj.

\section{ZAKLJUČAK}

Osobe starije životne dobi, kao i svako drugo ljudsko biće, trebaju pažnju i skrb kada nisu u stanju same rješavati probleme i poteškoće na bilo kojoj razini. Njihova patnja najviše se očituje kroz osjećaj napuštenosti, beskorisnosti i bezvrijednosti. Kako im pomoći da nadvladaju bol (u fizičkom, psihičkom i duhovnom smislu) predstavlja izazov za različite stručnjake koji rade 
s njima, kao i njihove članove obitelji. Znanosti koje istražuju čovjekovu psihičku i tjelesnu razinu su ustrajne u traganju za novim otkrićima kako bi pospješile čovjekovo cjelokupno dobro. Filozofska antropologija prednjači u promatranju čovjeka s naglaskom na cjelovitost, uključujući i njegovu duhovnu dimenziju. I na području neuroznanosti bilježimo rezultate istraživanja koji biološkim činjenicama kojima se pridružuju i one psihološke, potvrđuju da smo na putu dobrog traganja samo ako pored tjelesnog i psihičkog aspekta čovjeka promatramo i onaj duhovni. I kroz teorije starenja, kao i njihovu praktičnu primjenu, otkriva se duhovnost kao važna čovjekova dimenzija koja ne stari, nego dozrijeva. Upravo kroz gerotranscendenciju kao zadnju fazu životnog ciklusa, život postaje cjelina, a na starost se gleda kao na pozitivno životno razdoblje u kojem imamo zadaću »otpustiti« materijalno i osobno te sagledati proživljeno kroz »meta-perspektivu« duhovnog i univerzalnog.

Duhovne potrebe starijih osoba trebaju biti prepoznate u okruženju gdje one žive, baš kao i one biološke, psihološke i socijalne. Stoga je važna edukacija stručnjaka različitih profila koji rade sa starijim osobama o duhovnoj dimenziji čovjeka i potrebama koje iz nje proizlaze. Edukacija bi trebala biti namijenjena svim stručnjacima koji rade sa starijim osobama. Ovisno o razini pružanja skrbi kao i težini bolesti i/ili samostalnosti starije osobe svakako treba voditi računa i o razini znanja, vještina i kompetencija iz područja duhovnosti koje stručnjaci trebaju imati. No, za početak bi bilo dovoljno osvijestiti pristup koji u prvi plan stavlja osobu, a ne bolest, odnosno oštećenje koje ona ima. Program edukacije iz područja duhovnosti trebao bi osobu osposobiti za: razumijevanje različitih koncepata duhovnosti (tradicionalnog i modernog), dati smjernice za procjenu stanja osobe u kojima duhovnost može koristiti kao način suočavanja i/ili osnaživanja (npr. u suočavanju s velikim životnim gubicima, kroničnom boli, smrću i umiranjem, osamljenošću, zlostavljanjem i zanemarivanjem).

Pristup koji promatra svakog pojedinca kao cjelinu kojoj treba težiti, čije nezadovoljene potrebe narušavaju sklad i cjelovitost svih drugih, treba biti prepoznat i u radu s osobama starije životne dobi, posebno u području socijalnog rada, medicine i pastorala. Kada osoba otkrije i prihvati sebe kao neponovljivu i cjelovitu (bez obzira na dob, izgled, bolest, poteškoću) te ako i okolina (obitelj i šira zajednica) starost promatra kao darovano vrijeme, tada u zrcalu duhovnosti možemo vidjeti unutarnji ,make up“ starosti kroz ljepotu zajedništva, prihvaćanja, praštanja i životne mudrosti neophodnih za razumijevanje smisla života. 


\section{LITERATURA}

Agostino, J.N. (1987): Religiosity and religious participation in the later years: A reflection of the spiritual needs of the elderly. Journal of Religion and Aging, 4(2), 75-82.

Aponte, H. (2002): Spirituality: the heart of therapy. Journal of Family Psychotherapy, 13, 13-27.

Ayele, H., Mulligan, T., Gheorghiu, S., \& Reyes-Ortiz, C. (1999): Religious activity improves life satisfaction for some physicians and older patients. Journal of the American Geriatrics Society,47(4), 453-455.

Baker, D.C. (2000): The investigation of pastoral care interventions as a treatment for depression among continuing care retirement community residents. Journal of Religious Gerontology, 12(1), 63-85.

Bickerstaff, K.A., Grasser, C.M., \& McCabe, B. (2003): How elderly nursing home residents transcend losses of later life. Holistic Nursing Practice, 17(3), 159-165.

Bondevik, M., Skogstad, A. (2000): Loneliness, religiousness, and purpose in life in the oldest old. Journal of Religious Gerontology, 11(1), 5-21.

Coleman, P.G. (1999): Creating a life story: The task of reconciliation. Gerontologist, 39(2), 133-139.

Crisp, B.R. (2010): Spirituality and Social Work. Surrey, UK: Ashgate Publishing.

Despot Lučanin, J. (2003): Iskustvo starenja - doprinos teoriji starenja. Zagreb: Naklada Slap.

Eisenhandler, S.A. (2005): "Religion is the finding thing": An evolving spirituality in late life. Journal of Gerontological Social Work, 45(1-2), 85-103.

Erikson, E.H., Erikson, J.M. (1997): The Life Cycle Completed. New York: Norton.

Erikson, E.H. (2008): Identitet i životni ciklus. Beograd: Zavod za udžbenike.

Frankl, V.E. (2010): Čovjekovo traganje za smislom. Zagreb: Planetopija.

Graves, D.L., Shue, C.K., Arnold, L. (2002): The role of spirituality in patient care: incorporating spirituality training into medical school curriculum. Academic Medicine, 77, 1167.

Hall, B., Scrag, T. (2012): Social Work with Older People - Approaches to Perosn-Centred Practice. New York: Open University Prress.

Hill, P.C., Pargament, K.I. (2003): Advances in the conceptualization and measurement of religion and spirituality. Implications for physical and mental health research. American Psychologyst, 58, 64-74.

Jewell, A. (2011): Spirituality and Personhood in Dementia. London: Jessica Kingsley Publisher.

Kitwood, T. (1997): Dementia Reconsidered: The Person Comes First. Buckingham: Open University Press.

Kitwood, T., Bredin, K. (1992): A new approach to the evaluation of dementia care. Journal of Advances in Health and Nursing Care, 1(5), 41-60.

Koenig, H.G. (1994): Aging and God: Spiritual Pathways to Mental Health in Midlife and Later Years. New York: The Haworth Pastoral Press.

Koenig, H. G., King, D. E., Carson, V. B. (2012): Handbook of religion and helath. (str. 38). Oxford, NewYork: Oxford University Press.

Krause, N. (2004): Stressors in highly valued roles, meaning in life, and the physical health status of olde radults. Journal of Gerontology Social Sciences, 59, S287-297.

Lewin, F.A., Thomas, L.E. (2001): Gerotranscendence and life satisfaction: Studies of religious and secular Iranians and Turks. Journal of Religious Gerontology, 12, 17-41.

Liang, J. (2011): Components of a meaningful retirement life - a phenomenological study of the 1950s birthcohortin urban China. Journal of Cross-Cultural Gerontology, 26, 279-298. 
MacKinlay, E. (2001): The spiritual dimension of caring: applying a model for spiritual tasks of aging. Journal of Religous Gerontology, 12, 151-166.

MacKinlay, E. (2001a): The Spiritual Dimension of Aging. London: Jessica Kingsley Publisher.

MacKinlay, E. (2006): Spiritual Growthand Care in the Fourtg Age of Life. London: Jessica Kingsley Publisher.

McFadden, S. (1996): Religion, spirituality, and aging. In: Birren, J. E., Schaie, K.W. (ur.): Handbook of the Psychology of Aging. (str. 162-177). San Diego: Academic Press.

McSherry, W. (2006): Making Sense of Spirituality in Nursing and Healthcare Practice. London: Jessica Kingsley Publishers.

Moffitt, L. (1999): The Spiritual Needs of People with Dementia. Derby: Methodist Homes for the Aged and Christian Council on Ageing.

Mowat, H. (2004): Successful aging and the spiritual journey. In: Jewell, A. (ur.) Aging, Spirituality and Well-being. (str. 42-57). London: Jessica Kingsley.

Murray, R.B., Zentner, J.B. (1989): Nursing Concepts for Health Promotion. London: Prentice Hall.

Ortiz, L., Langer, N. (2002): Assessment of spirituality and religion in later life: acknowledging clients' needs and personal resources. Journal of Gerontoogical Soial Work, 37, 5-21.

Pargament, K.I., Koenig, H.G., Tarakeshwar, N., Hahn, J. (2001): Religious struggle as a predictor of mortality among medically ill elderly patients: a 2-year longitudinal study. Archives of Internal Medicine Journal, 161, $1881-1885$.

Parsons, M. (2001): Living at home. In: Cantley, C. (ur.): Handbook of Dementia Care. (str. 123-134). Buckingham: Open University Press.

Post, S.G., Puchalski, C.M., Larson, D.B. (2000): Physicians and patient spirituality: professional boundaries, competency, and ethics. Annals of Internal Medicine, 132(7), 578-83.

Schaie, K. W., Willis, S. L. (2001): Psihologija odrasle dobi i starenja. (str. 303). Zagreb: Naklada Slap.

Sloan, R., Bagiella, E., Powell, T. (1999): Religion, spirituality and medicine. The Lancet, 353, 664-7.

Tooth, G., Linell, A. (2012): Work with older people and spirituality. In: Hall, B., Scragg, T. (ur.): Social Work with Older People - Approaches to Perosn-Centred Practice. (str. 161-176). New York: Open University Press.

Tornstam, L. (1989): Gero-transcedence: A meta - theoretical reformulation of the disengagement theory. Aging, Clinical and Experimental Research, 1(1), 55-63.

Tornstam, L. (1994): Gerotranscendence: A theoretical and empirical exploration. In: Thomas, L.E., Eisenhandler, S.A. (ur.). Aging and Religious Dimension. (str. 203-225). Greenwood Publishing Group Westport.

Tornstam, L. (1996): Caring for the elderly. Introducing the theory of gerotranscendence as a supplementary frame of reference for caring for the elderly. Scandinavian Journal of Caring Sciences, 10, 144-150.

Tornstam, L. (1997): Life crises and gerotranscendence. Journal of Aging and Identity, 2, 117-131.

Tornstam, L. (2000): Transcedence in later life. Generation, 33(4), 10-14.

Wadensten, B., Carlsson, M.A. (2001): Qualitative study of nursing staff members' interpretations of signs of gerotranscendence. Journal of Advced Nursing, 36, 635- 642.

Wadensten, B., Carlsson, M. (2003): Theory-driven guidelines for practical care of older people, based on the theory of gerotranscendence. Journal of Advced Nursing, 41, 462-470.

Weiss, T. (2013): Personal transformation: posttraumatic growth and gerotranscendence. Journal of Humanistic Psychology, XX(X), 1-24. 


\section{AGING AND OLD AGE IN THE MIRROR OF SPIRITUALITY}

Abstract: This paper describes spirituality as an area that is becoming increasingly relevant in working with the elderly in both health and social types of care. Spiritual and spirituality are rarely mentioned in theories of aging. Within the theory of psychosocial development, spirituality can be recognised in the ninth phase, i.e. the stage of gerotranscendence. Accepting one's own infirmity or dependence can be a source of growth, and the opportunity to develop spiritual qualities (patience, gratitude, pleasure in small things, satisfaction because I exist and live), and it also provides a new opportunity for reevaluation of one's entire life by giving a new meaning to all that was lived. According to the developmental theory of positive aging, people who grow in age gradually approach the meta-perspective, i.e. they gradually abandon the perceptible, tangible, visible and material vision of life and of the world and acquire the cosmic-transcendent vision. This work points to the need for education of professionals who work with older people on the importance of recognising their spiritual needs.

Keywords: the elderly, spirituality, spiritual needs, gerotranscendence, developmental theory of positive aging 